\title{
Corporate Governance on Share Price Performance of Big Cap Issuers During Covid-19 Pandemic
}

\author{
Niken Kusumawardani \\ \{nicken_kusumawardani@yahoo.co.id\}
}

Faculty of Economics and Business, University of Lampung, Jl. Sumantri Brojonegoro, Bandar lampung, Indonesia

\begin{abstract}
This study aims to determine the effect of corporate governance on the share price performance of big cap issuers during the Covid-19 pandemic in Indonesia. In this study, corporate governance used five components such as institutional ownership, board size, CEO duality, independent commissioners and ownership concentration while share price performance used stock returns. Hypothesis testing using multiple linear regression. The sample of this research included twenty corporate of big cap issuers in Indonesia Stock Exchange (BEI). The results of hypothesis testing indicate that there is an insignificant relationship between the variables of institutional ownership, board size, CEO duality, and independent commissioners on stock returns, while ownership concentration indicate a significant negative relationship with stock returns during the Covid-19 pandemic. From the results of the study, the components of corporate governance on share price performance during Covid-19 pandemic need more researchable.
\end{abstract}

Keywords: corporate governance, share price performance, big cap issuers, Covid-19

\section{Introduction}

Currently, the world is facing a health crisis that impacts on the economic sector. The Covid-19 pandemic has started to have an economic impact in Indonesia since the implementation of work from home and large-scale social restrictions (PSBB). Most of the activities of human life are carried out at home. Schools have begun to temporarily close, human mobility is limited, and the obligation to carry out self-quarantine. Indonesian economic data released by BPS shows the number $2.97 \%$ in the first quarter while in the second quarter it must decrease by $5.22 \%$ or $-5.32 \%$. This shows an economic contraction in the second quarter of the Indonesian economy. The company as a business entity must have a precise strategy to continue to survive in the midst of external attacks due to the pandemic. Corporate governance is a system or corporate structure designed to carry out company operations. Corporate governance began to be echoed in Indonesia since the 1998 financial crisis. At that time, corporate governance was considered very weak in implementation in several companies in Indonesia, so that the recovery process for the financial crisis was very slow [1]. Corporate governance is a form of accountability carried out by directors and managers, as outlined in the company's strategy which refers to achieving goals, risk control and responsible use of company resources [2]. Control risk in this case is pandemic risk. Companies through corporate governance are expected to be able to overcome the impact of Covid-19 with a series of internal company structures so that they can create a company that is sustainable and credible in the eyes of investors. Corporate governance is useful for protecting investors from the differences in the interests of majority and minority shareholders in a company [3]. Share price performance can be measured using stock returns or stock returns [4]. In Indonesia, there are issuers that are categorized as big cap or blue chip issuers. Issuers that are included in the big cap category are those with large market capitalization and good fundamental performance. This research will discuss corporate governance on stock returns during the Covid-19 pandemic that occurred in Indonesia. Corporate governance in this study is represented by components based on indicators carried out from previous studies [2], [5], namely, institutional ownership, ownership concentration, board of directors, independent board of commissioners, and CEO duality. Meanwhile, stock performance in this study uses a variable stock return or stock return. Several previous studies have stated that institutional ownership has an effect on stock returns [2] while [6] suggests that institutional ownership has no effect on stock returns. For the component corporate governance represented by the board of directors, the results show that the board of directors has a positive and insignificant effect on firm value [7], while the research results [2] state that the board of directors has a negative significant to the stock return. The duality of CEO or concurrent positions by the board of directors and commissioners in the company has a negative relationship to company performance [8], while according to [2] CEO duality has a positive relationship to stock returns. 
Figure 1. Market Capitalization of Big Ten Big Cap Issuers on June 2020

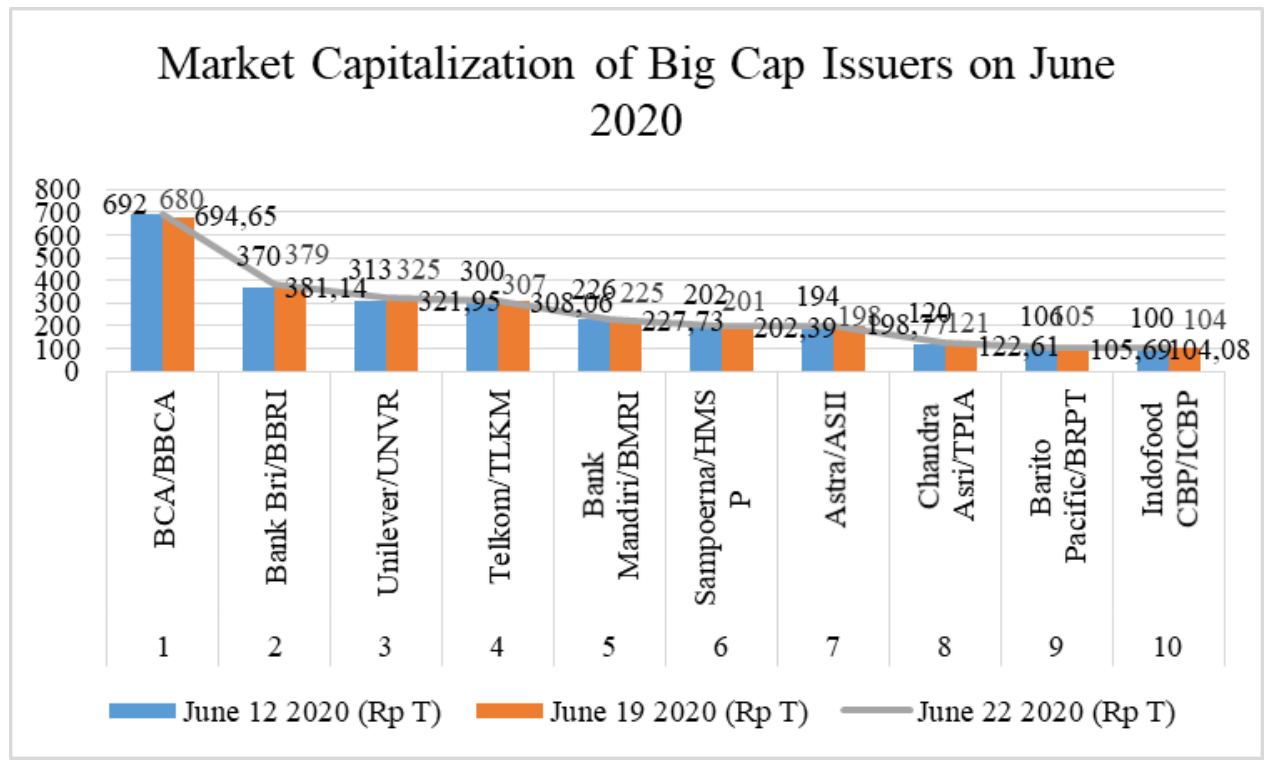

(Source: idx.co.id, 2020)

Based on the empirical evidence and previous studies which have different results, this study will examine the effect of corporate governance as represented by the component of institutional ownership, concentration ownership, board of directors, independent board of commissioners and CEO duality on the stock performance of big cap issuers during the Covid-19 pandemic.

\section{Literature Review}

Agency theory according to [9] is the existence of a contractual relationship between an agent (manager) consisting of one or two or more people who give the principal (shareholder) rights and authority to perform services on behalf of agent and making business decisions in the best interests of the principal. However, in reality, sometimes there are differences in interests or goals between the agent and the principal. This is where the agency conflict occurs. The relationship between agent and principal can be created conducive and responsibly through the implementation of corporate governance so as to improve company performance [10]. [2] in research on the effect of corporate governance on stock returns on the Tehran Stock Exchange. The results of this study indicate that there is a significant positive effect of elements corporate governance on stock returns. The elements of corporate governance use institutional ownership, independent commissioners, dual CEO positions and CEO tenure. [11] in research on the effect of corporate governance on fluctuations in stock returns during the financial crisis, it is stated that there is a relationship between independent commissioners and outside directors on fluctuations in stock returns. [12] states that there is a positive and significant relationship between corporate governance and stock returns. The research conducted by [13] entitled the results of the corporate governance perception index which refers to the implementation of the corporate governance component has an effect on stock price volatility. The hypothesis in this study is as follows:

$\mathrm{H}_{1}$ : Institutional ownership (INST_OWN) has a significant positive effect on big cap stock returns during Covid-19

$\mathrm{H}_{2}$ : Board size (BRD_SIZE) has a significant positive effect on big cap stock returns during Covid-19

$\mathrm{H}_{3}$ : CEO duality (CEO_DUAL) has a significant positive effect on big cap stock returns during Covid-19

$\mathrm{H}_{4}$ : Independent commissioners (BRD_INDPC) have a significant positive effect on big cap stock returns during Covid-19

$\mathrm{H}_{5}$ : Ownership concentration (OWN_CONST) has a significant positive effect on big cap stock returns during Covid-19

\section{Methodology \& Data Analysis}

Testing the hypothesis in this study using multiple linear regression statistical analysis using software SPSS26. The type of data in this study uses secondary data available on the IDX website (idx.co.id). The 
research sample used purposive sampling method, namely companies in the category big cap or issuers with large market capitalizations totaling 20 companies. The independent variable in the study uses institutional ownership, ownership concentration, board of directors, independent commissioners and CEO duality, while the dependent variable in this study uses stock returns or stock returns. The multiple linear regression equation in this study is described as follows:

STOCK_RETURN $=\alpha+\beta($ INST_OWN $)+\beta\left(B R D \_S I Z E\right)+\beta\left(C E O \_D U A L\right)+\beta\left(B R D \_I N D P C\right)+\beta\left(O W N \_C O N S T\right)$ $+\varepsilon \ldots \ldots \ldots \ldots \ldots \ldots \ldots \ldots \ldots \ldots \ldots \ldots \ldots \ldots \ldots \ldots(1)$

In which:

\begin{tabular}{|c|c|}
\hline STOCK_RETURN & $=$ Stock Return \\
\hline$\alpha$ & $=$ Constant \\
\hline INST_OWN & $=$ Institutional Ownership \\
\hline BRD_SIZE & $=$ Board Size \\
\hline CEO_DUAL & $=$ CEO Duality \\
\hline BRD_INDPC & = Board Independence \\
\hline OWN_CONST & $=$ Ownership Concentration \\
\hline$\varepsilon$ & $=$ Error term \\
\hline
\end{tabular}

Measurement of the dependent variable, namely stock return (STOCK_RETURN) using the formula [14] which states that stock returns can be measured using the difference between the current stock price and the previous period's stock price in the previous period's stock price. The measurement of the independent variable in this study, namely institutional ownership (INST_OWN), is a comparison of the number of issuers' shares owned by the institution to the number of shares outstanding [15]. The size of the board of directors (BRD_SIZE) is the number of members of the board of directors and commissioners in a company [16]). Duality CEO (CEO_DUAL) is a member of the board of commissioners and board of directors [17] Independent commissioner (BRD_INDPC) is the ratio of the number of independent commissioners to the number of commissioners [18] Concentration of ownership (OWN_CONST) is the ratio of the largest number of share ownership to total shares [18].

\section{Result \& Discussion}

In this study there are five independent variables, namely institutional ownership (INST_OWN), board size (BRD_SIZE), CEO duality (CEO_DUAL), independent commissioner (BRD_INDPC), ownership concentration (OWN_CONST), while the dependent variable is stock returns. (STOCK_RETURN). The following table of descriptive statistical results of the study variables:

Table 1. Descriptive Statistics Test Results

\begin{tabular}{|l|r|r|r|r|r|r|}
\hline & INST_OWN & BRD_SIZE & CEO_DUAL & BRD_INDPC & OWN_CONST & STOCK_RETURN \\
\hline Mean & 71,949500 & 14,45 &, 15 &, 449145 &, 574410 &,- 306330 \\
\hline Maximum & 99,5000 & 25 & 1 &, 8000 &, 9522 &, 1786 \\
\hline Minimum & 26,3100 & 9 & 0 &, 2857 &, 1019 &,- 8244 \\
\hline $\begin{array}{l}\text { Std. } \\
\text { Deviation }\end{array}$ & 26,5395206 & 3,790 &, 366 &, 1259011 &, 1974013 &, 2329754 \\
\hline N & 20 & 20 & 20 & 20 & 20 & 20 \\
\hline
\end{tabular}

Source: processed data, 2020.

Based on the descriptive statistical output, it can be explained that:

1. The variable return stock (STOCK_RETURN) has a minimum value of $-0,8244$ and a maximum value of 0,1786 . This shows that the amount of returns stock in the sample of this study ranged from $-0,8244$ to 0,1786 with an average (mean) $-0,306330$ at a standard deviation of 0,2329754 .

2. The Institutional Ownership variable (INST_OWN) has a minimum value of 26, 3100 and a maximum value of 99,5000 . This shows that the amount of share ownership in the sample of this study ranged from 26, 3100 to 99,5000 with an average (mean) of 71,949500 with a standard deviation of 26 , 5395206.

3. The variable of board size (BRD_SIZE) has a minimum value of 9 and a maximum value of 25 . This indicates that the size of the board of directors in the sample of this study ranges from 9 to 25 with an average (mean) of 14, 45 in the standard deviation of $3,790$. 
4. The CEO duality variable (CEO_DUAL) has a minimum value of 0 and a maximum value of 1 . This shows that the magnitude of CEO duality in the sample of this study ranges from 0 to 1 with an average (mean) of 0,15 at a standard deviation of 0,366 .

5. The independent commissioner variable (BRD_INDPC) has a minimum value of 0,2857 and a maximum value of 0,8000 . This shows that the number of independent commissioners in the sample of this study ranged from 0,2857 to 0,8000 with an average (mean) 0, 449145 with a standard deviation of 0,1259011 .

6. The ownership concentration variable (OWN_CONST) has a minimum value of 0, 1019 and a maximum value of 0,9522 . This shows that the magnitude of the concentration of ownership in the sample of this study was 0,1019 to 0,9522 with an average (mean) of 0,574410 with a standard deviation of 0,1974013 .

Table 2. Research Hypothesis Test Results

\begin{tabular}{|l|r|r|r|}
\hline & Coefficient & t-statistics & sig \\
\hline Constant &, 440 & 1,725 &, 107 \\
\hline INST_OWN &, 000 &,- 186 &, 855 \\
\hline BRD_SIZE &,- 008 &,- 628 &, 540 \\
\hline CEO_DUAL &, 168 & 1,484 &, 160 \\
\hline BRD_INDPC &,- 487 & $-1,494$ &, 157 \\
\hline OWN_CONST &,- 729 & 3,270 &, 006 \\
\hline
\end{tabular}

Source: processed data, 2020

Based on table 2 of the results of hypothesis testing it can be concluded that:

1. The independent variable institutional ownership has a significant value of 0.855 and a beta value of 0.000 , which means that the independent variable institutional ownership has no effect on stock return. The existence of institutional ownership should encourage better supervision of the company's performance [19]. This non-effect result is due to the focus of institutional ownership on current earnings. The condition of company profits that tend to fluctuate and even negatively occur in several companies, including big cap issuers during the Covid-19 pandemic, caused a tendency for institutional parties to withdraw their shares and resulted in a decline in share prices.

2. The independent variable board size has a significant value of 0.540 and a beta value of -0.008 , which means that the independent variable board size has no effect on stock return. These results indicate that in a company if the size of the board of directors is large enough, it can be said to be ineffective and inefficient in monitoring the performance of company management in improving stock quality. This is due to the difficulty of communicating and coordinating among members of the board of commissioners and the decision-making process takes a long time due to government instructions regarding work from home and large-scale social recording (PSBB). A number of oversight carried out by the board of commissioners and directors in large or small amounts produces the same quality [20].

3. The independent variable CEO duality has a significant value of 0.160 and a beta value of 1.68 , which means that the independent variable CEO duality has no effect on returns stock. The existence of CEO duality within a company does not have a significant impact on the level of share control as long as the board in office has integrity and a good professional attitude so that policies can still be determined effectively and efficiently, moreover, there are rules in the organizational structure applied in Indonesia that do not allow them to exist. CEO duality, but for some reason the company can exercise CEO duality but with disclosures in the annual report. CEO duality has no significant effect on company performance [21], [22].

4. The independent variable for independent commissioners has a significant value of 0.157 and a beta value of -0.487 , which means that the independent variable of independent commissioners has no effect on stock return. These results indicate that the role of the independent board of commissioners cannot improve stock quality through the monitoring function of financial reporting and there is low awareness of the importance of the GCG system in improving the quality of company value. In addition, the company does not need many independent commissioners because the addition or placement of independent commissioners may only be to fulfill the regulations of the government as supervisors in the company, and the increasing number of independent commissioners will burden the company regarding the expenses of salaries and other costs that will affect the return of the company [20].

5. The independent variable of ownership concentration has a significant value of 0.006 and a beta value of 0.729 , which means that the ownership concentration variable has a negative effect on stock return. Ownership concentration is a mechanism that refers to the proportion of a company's shares in the largest number of shareholders. The high number of concentrated shares will trigger pressure on managers to act in the interests of shareholders [23]. Investors with the largest proportion of shares 
have a tendency to compromise or side with management and ignore the interests of minority shareholders [24]. The assumption that management often took non-optimal actions or policies during the Covid-19 pandemic resulted in high shareprice fluctuations. Based on the table of hypothesis testing results, the variable testing model in this study is as follows:

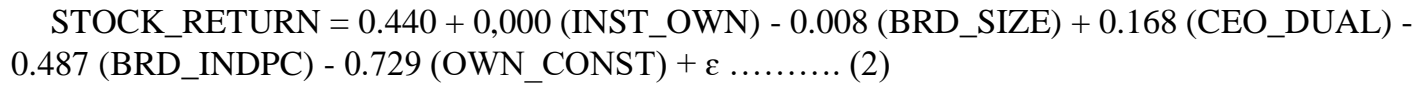

\section{Conclusion}

The results indicate that the implementation of corporate governance during the pandemic tends to be suboptimal and has the potential to weaken share price performance, in this case the stock return. Future research can add several corporate governance indicators that are relevant to the business environment during the pandemic and increase the sample size of companies other than big cap issuers.

\section{Implications/Limitations \& Suggestions for Further Research}

The implication of this research is to provide an overview of the evaluation of companies regarding corporate governance that has been carried out during the Covid-19 pandemic, meanwhile for the investors, can be used for monitoring the performance of share prices during the pandemic period and to take the decisions about investment safely, while for the government it can be used as an early warning against stock market conditions that occurred in Indonesia during the Covid-19 pandemic. Further research can be used another measurement components of corporate governance outside from this paper.

\section{References}

[1] F. Winata, "Pengaruh Corporate Governance Terhadap Tax Avoidance Pada Perusahaan Yang Terdaftar Di Bursa Efek Indonesia Tahun 2013,” Tax Account. Rev., vol. 4 (1), no. 1, pp. 1-11, 2014.

[2] S. Rostami, Z. Rostami, and S. Kohansal, "The Effect of Corporate Governance Components on Return on Assets and Stock Return of Companies Listed in Tehran Stock Exchange," Procedia Econ. Financ., vol. 36, no. 16, pp. 137-146, 2016, doi: 10.1016/s2212-5671(16)30025-9.

[3] F. Damayanti and T. Susanto, "Pengaruh Komite Audit, Kualitas Audit, Kepemilikan Institusional, Risiko Perusahaan Dan Return on Assets Terhadap Tax Avoidance," Esensi, vol. 5, no. 2, pp. 187-206, 2016, doi: 10.15408/ess.v5i2.2341.

[4] F. J. Fabozzi, P. P. Peterson, and W. D. Habegger, Financial Management and Analysis Workbook: Step-by-Step Exercises and Tests to Help You Master Financial Management and Analysis, 2nd ed. New Jersey: John Wiley \& Sons, Inc, 2004.

[5] Ş. Cristian Gherghina, "Corporate Governance Ratings and Firm Value: Empirical Evidence from the Bucharest Stock Exchange," Int. J. Econ. Financ. Issues, 2015.

[6] C. Tewu, S. Murni, J. M. Dampak, and F. Kark, "Dampak Faktor Karakteristik Perusahaan Dan Faktor Bursa Efek Indonesia Terhadap Return Saham (Pada Industri Keuangan Non Bank Yang Terdaftar Di Bei Periode 2013-2017),"

J. EMBA J. Ris. Ekon. Manajemen, Bisnis dan Akunt., vol. 8, no. 1, pp. 2169-2179, 2020, doi: 10.35794/emba.v8i1.28169.

[7] A. M. P. Sari and P. A. Ardiana, "Pengaruh Board Size Terhadap Nilai Perusahaan," E-Jurnal Akunt. Univ. Udayana, vol. 7, no. 1, pp. 177-191, 2014.

[8] A. Ujunwa, "Board characteristics and the financial performance of Nigerian quoted firms," Corp. Gov., vol. 12, no. 5, pp. 656-674, 2012, doi: 10.1108/14720701211275587.

[9] M. C. Jensen and W. H. Meckling, "Theory of the firm: Managerial behavior, agency costs and ownership structure," J. financ. econ., 1976, doi: 10.1016/0304-405X(76)90026-X.

[10] W. M. Putra, "Pengaruh Konflik Keagenan Terhadap Corporate Governance dan Kinerja Perusahaan," Maksimum, vol. 1, no. 2, pp. 109-114, 2011.

[11] M. Aloui, A. Jarboui, A. Mouna, and J. Anis, "The effects of corporate governance on the stock return volatility: During the financial crisis," Int. J. Law Manag., vol. 60, no. 2, pp. 478-495, Jan. 2018, doi: 10.1108/IJLMA-012017-0010.

[12] C. Jao, Robert; Mardiana, Ana; Jimmiawan, "Pengaruh Corporate Governance Terhadap Return Saham Melalui Manajemen Laba,” Tangible J., vol. 4, no. 1, pp. 139-161, 2019, doi: 10.21831/nominal.v6i2.16652.

[13] I. G. B. Y. Wiryakusuma, "Pengaruh Corporate Governance Terhadap Volatilitas Harga Saham," J. Ris. Akunt. dan 
Keuang. Fak. Bisnis UKDW, vol. 15, no. 1, pp. 1-10, 2019, doi: 10.1017/CBO9781107415324.004.

[14] Ross et al., Solutions Manual: Fundamentals of Corporate Finance 8th edition. 2017.

[15] E. Murwaningsari, "Pengaruh Struktur Kepemilikan Terhadap Return Saham," Media Ris. Akuntansi, Audit. dan Inf., vol. 12, no. 1, p. 45, 2012, doi: 10.25105/mraai.v12i1.586.

[16] G. Karuniajaya, Hartono, and Saarce, "Pengaruh board structure terhadap firm performance melalui intellectual capital pada perusahaan sektor barang konsumsi , perdagangan, jasa dan investasi pada perusahaan yang terdaftar di Bursa Efek Indonesia,” Bus. Account. Rev., vol. 5, no. 2, pp. 157-168, 2017.

[17] A. M. Setyawan and Devie, "Pengaruh CEO Duality Terhadap Firm Value Dengan Financial Performance Sebagai Variabel Intervening,” Bus. Account. Rev., vol. 4, no. 1, pp. 325-336, 2017.

[18] M. Rehman, R. Rehman, and A. Raoof, "Does corporate governance lead to a change in the capital structure?," Am. J. Soc. Manag. Sci., 2010, doi: 10.5251/ajsms.2010.1.2.191.195.

[19] K. M. Islamiya, "Pengaruh Kinerja Keuangan Dan Struktur Kepemilikan Terhadap Return Saham," J. Ilmu dan Ris. Akunt., vol. 5, pp. 1-16, 2016, [Online]. Available: https://ejournal.stiesia.ac.id.

[20] M. A. Tertius and Y. J. Christiawan, "Pengaruh Good Corporate Governance Terhadap Kinerja Perusahaan Pada Sektor Keuangan," Bus. Account. Rev., vol. 3, no. 1, pp. 223-232, 2015, doi: 10.17509/jaset.v1i1.8907.

[21] D. Di Berardino, "Corporate Governance and Firm Performance in New Technology Ventures," Procedia Econ. Financ., vol. 39, no. November 2015, pp. 412-421, 2016, doi: 10.1016/s2212-5671(16)30342-2.

[22] U. Detthamrong, N. Chancharat, and C. Vithessonthi, "Corporate governance, capital structure and firm performance: Evidence from Thailand,” Res. Int. Bus. Financ., vol. 42, no. July, pp. 689-709, 2017, doi: 10.1016/j.ribaf.2017.07.011.

[23] A. Maman Tachiwou, "Corporate Governance and Firms'Financial Performance of Listed Company in the West African Monetary Union (Wamu) Regional Financial Exchange," Int. J. Econ. Financ., 2016, doi: 10.5539/ijef.v8n8p212.

[24] J. Pound, "Proxy contests and the efficiency of shareholder oversight," J. financ. econ., 1988, doi: 10.1016/0304405X(88)90046-3. 